\title{
ロのカラー動画像を用いた音韻認識
}

\author{
正員 寺 田賢 治 (徳島大学) \\ 非会員 山 中 理聖子 (徳島大学) \\ 非会員 大 恵 俊一郎 (徳島大学)
}

\section{Phoneme Recognition by Using a Sequence of Color Lip Images}

Terada Kenji, Member, Yamanaka Rikiko, Non-member, Oe Shun'ichiro, Non-member (The University of Tokushima)

In this paper, we propose a method for recognizing phoneme by using a sequence of color lip images. The mouth images are obtained in series by using the color camera set at the front of the face. First, among the sequence of the images, each object image for processing is detected by using mouth movement information. Next step, in each image, the mouth region is detected by the color information. Then, the four shapes which are outside line of lip, the inside line of lip, the tangue and the center line of lip are extracted by using the change in distribution of gray level. Finally, the recognition of phoneme is carried out by the method based on the subspace method. As the training, the subspace method needs the 20 features extracted from the above four shapes. In this paper, the authors describe the results of the experiments which were performed to demonstrate the effectiveness of the proposed method.

キーワード：読喜，音韻認識，画像認識，部分空間法

\section{1.はじめに}

日常的に人が人に自分の意志や考えを伝える手段として， 言葉が用いられる。このうち現在の計算機の発展に伴い,人 の言葉の認識を機械にさせようとする試みが行なわれはじ めたが，それは人が発した音声パターンに注目したものが 主である、しかしながら，騒音が多い場所や，同時に2人 以上が話している場合，また話し手がマイクなどから遠い 場合など，音声による認識が難しい場合がある ${ }^{(3)}$.ここで 人間同士の言葉の伝達を考えた場合，音声のみならず，話 している人の顔, すなわちロの形状の変化に注目していれ ば，少々音声が聞き取りにくくても，その人が言っている ことを推測することが可能である.さらに進めれば読唇術 などと言われるような視覚的な口の形状のみから言葉を認 識することも可能である，また，そのような積極的に読み 取る場合とは異なり，例えば，吹替えされた外国映画など で，視聴者は画面中の外国人が話しているところを見なが ら日本人の声優の声を聞くのだが，その際に違和感を感じ ることがある。これは, 視覚的な俳優の口形と聴覚的な声 優が発音する音韻のずれにその主な原因であり，無意識の うちに口の形状からも言葉を認識していると言える。ここ でもし外国語の音韻と日本語の音韻を一致，もしくはほ とんどー致させることができるならば，違和感はかなり楥
和されるはずである。

これに対して，画像処理に基づく音韻認識に関する研究 がなされているが(1)(2)(3)，まだこれと言う程，確立された 手法はない。これは，まず口領域の抽出が難しいことがあ げられる，すなわち，画像中の唇領域付近の濃度変化が緩 やかなため，唇領域と肌領域の境界が明確ではないため である，そのため唇に黑色を塗ってもらった上でデータを 取得したり(1)，スプライン関数などでフィッティングした り (2)，さらに唇領域を抽出せずに，まわりの筋肉の動きに 着目したり(3)していた，また，音韻の認識に用いる特徴量 が，唇輪郭線だけであったり，口の絴横比であったりと，口 の外形に着目するものがほとんどであった。またその特徴 量も個性などの影響などを考慮していないものが多く，一 人の被験者に対する認識のみであったり(4), 複数の人で認 識を行なうと，途端に正解率が悪くなるものがほとんどで あった (3).

このような背景に鑑み，口のカラー画像より，唇の外周 形状, 内周形状, 舌形状, 唇重心線などを抽出し, それよ り求められる音韻を自動認識する方式の構築を試みる。本 方式ではまず，カラーカメラにより連続的に撮像された話 している人のカラー動画像から各音韻に対して，1フレー ムずつ切り出す。ここでは口に動きに着目し, 差分法を利 用してその音韻を最もよく表している画像フレームを取り 
出す. 次に決定されたその画像フレームに対して, 認識に 必要な口領域の抽出を行なう。ここではカラー画像を YIQ 表色系で表現したときに，唇では $\mathrm{Q}$ 成分が大きくなるこ とに注目し，判別分析法を用いて唇領域を決定，抽出する。 さらに抽出された口領域から, 画像の濃度変化を細かく注 目しながら, 口の外周, 口の内周, 舌、唇の重心線などを抽 出する，最後に部分空間法により各音韻を認識する．部分 空間を生成する特徴空間は，個性に影響を受けにくく，か つ各音韻の判別が可能な形状特徵, 濃度特徴により構成す る。これらはこれまで用いられることのなかった口の内部 の情報などを用いる。

本論文では，さらに，本アルゴリズムを実際の画像に適 用したときの実験結果を示し，その有効性を検証する。こ の実験では,「あ」「い」「う」「え」「打「ん」の 6 個の母音 を認識する。また今回は子音を認識対象としない。これは, 子音が発話されている時間は非常に短く，現在の技術では その画像データを取得することが難しいためである。ただ しアフレコのように視覚的な口形と聴覚的な音韻が不自然 にならないようにするのが目的なので母音だけ認識できれ ば良い場合や，読唇術のように母音さ元認識できていれば, 前後のつながりから言語処理的に子音を類推することも可 能である場合など，母音のみを対象として認識を行なって も各分野で大変有用となる.

\section{2. 処理フレームの抽出}

まず得られているカラー動画像系列中から，処理対象と する画像フレームを決定する。これは各音韻ごとに1枚づ つ, 音韻を最もよく表現していると思われる画像つレーム を取り出すものである。

ここでは，言葉を発する時，口の動きは，一度大きくなっ た後で収束することに着目し，差分法を用いてそれを決定 する(5).まず全画像系列の前後フレーム間で対応画素同士 の差分値の和を計算する，そしてそれが極大を検出した上 で，その直後の極小値となるフレームを検出すると，それ がその音韻を表す代表フレームとなる。

図1に, 横軸に画像フレーム番号, 檤軸に対応する画像つ レームの前後の差分值の和を示す．この例では被験者は「た んは」と発音している. 差分值が極小值になる画像フレー ムを抽出すると，人の目での評価であるが「た」と「ん」と 「ほ」がよく表現されている。

図2は決定された画像フレームの例である (実際はカラー 画像).これは「た」に関する代表フレームである。

\section{3. 口領域の抽出}

〈3.1〉口領域の外周の抽出処理フレーム画像中の口 領域の抽出を行なう. 唇の濃度变化はかなりゆるやかであ るため, 単純に白黒濃淡画像やカラー画像の輝度成分では, それを確寒に検出することが難しい，そこで，カラー情報 を YIQ 表色系 ${ }^{(6)}$ で表現した際の $\mathrm{Q}$ 成分が唇の色を最も強 調することに注目する(7)，RGB から $\mathrm{YIQ}$ 表色系への変

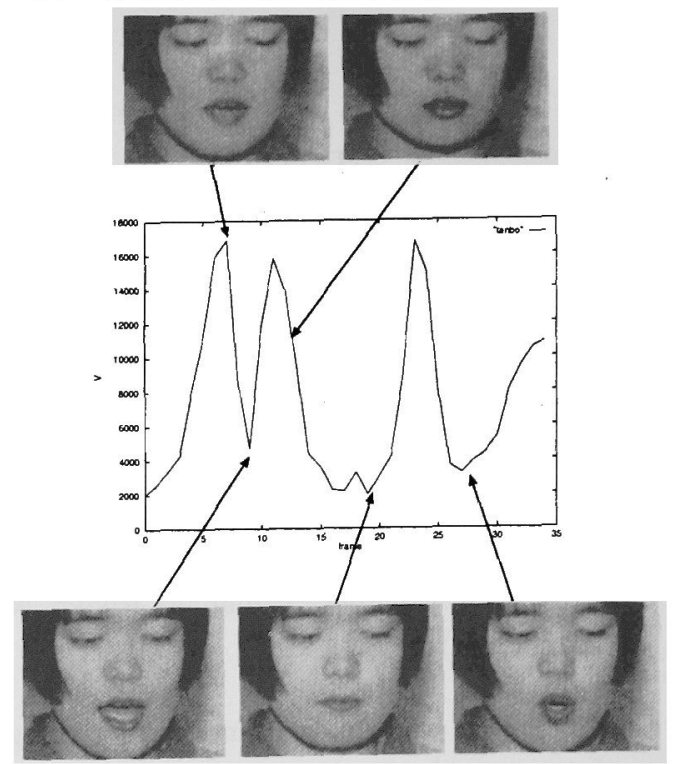

図 1 差分值の変化の例

Fig. 1. An example of difference between the frame

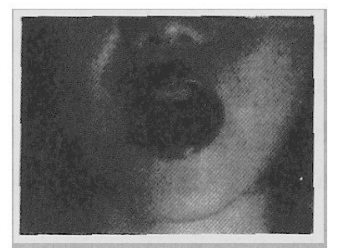

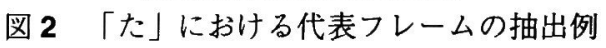
Fig. 2. An example of "ta" image detected by using mouth movement information

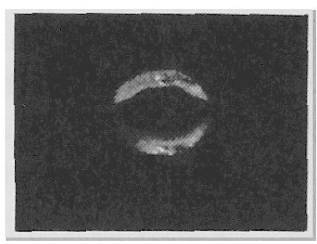

図 $3 \mathrm{Q}$ 成分画像

Fig. 3. An example of $Q$ image

換式は式 (1)のように示される.

$$
\left[\begin{array}{l}
Y \\
I \\
Q
\end{array}\right]=\left[\begin{array}{rrr}
0.299 & 0.587 & 0.114 \\
0.596 & -0.274 & -0.322 \\
0.211 & -0.522 & 0.311
\end{array}\right]\left[\begin{array}{l}
R \\
G \\
B
\end{array}\right]
$$

YIQ 表色系に扔いては，Y 信号は輝度情報を含み，I 信号 と Q 信号は色相情報と彩度情報を含んでいる。

ここで唇部分の $\mathrm{Q}$ 成分值が大きくなるが, 鼻や髮の毛の 部分などの中に粒状に值が高い領域も存在し，単純に固定 しきい値を用いて唇を抽出することは困難である。また人 により，または画像を撮影する条件により，唇の $\mathrm{Q}$ 成分の

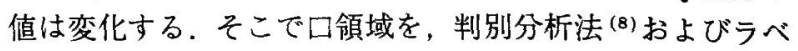
リング処理により抽出する。 


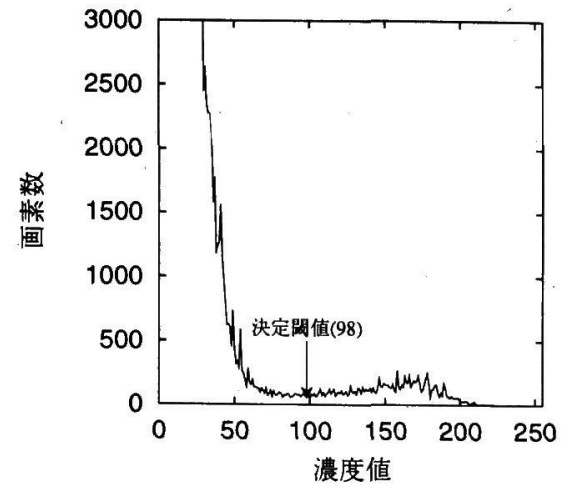

図 4 濃度ヒストグラム

Fig. 4. An example of gray lebel histogram

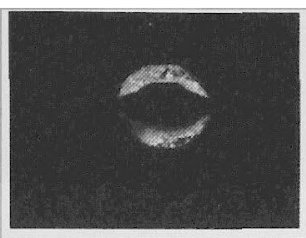

図 5 口領域検出結果画像

Fig. 5. An example of an image of detected mouth

図 3 に $\mathrm{Q}$ 成分画像の一例を示す，唇部分が強調されてい るのに対して，頪や首などの肌の部分ではその值が小さい. 図3の Q 成分画像における濃度ヒストグラムの例を図 4 に 示す.この例では, 判別分析法によりしきい值は 98 と決 定される.さらにこの値およびラベリング処理を用いるこ とで，抽出された口領域を図 5 に示す。結果，口領域が正 しく抽出されていることがわかる。またその境界が唇の外 周形状となる。

〈3-2〉 唇の内周の抽出 口の外周形状は個性に大変影 響され，この情報のみでは正しく認識することが難しい場 合がある. そこでさらに口の内側の抽出を行なって，口の 内側の情報を認識に用いる。ここでは口領域の $\mathrm{Q}$ 成分画像 に着目し，図6に示されるように，既に口領域が抽出され ている Q 成分画像の濃度微分值を用いる。ここでカラー 情報の輝度成分では，例えば唇の内周周辺において，唇領 域であるのに光の当り方の加減で暗くなっていても，口腔 なので暗くなっていても，その值は同じょうに小さくなり， その境界が明確とはならない場合がある，そこで，彩度成 分と色相成分を含んでいる Q 成分に着目する.

まず画像のある一列に着目する，そしてすでに検出され ている唇の境界線を始点として唇領域内で上下両方からラ スター走査により濃度值の微分值を調べる，そしてそれが あるしきい値以上になった画素が内側の境界線となる。こ れを位置を変えて繰り返すと, 唇全体の内周を抽出するこ とができる.

このアルゴリズムにて抽出された口内部領域の $\mathrm{Q}$ 成分

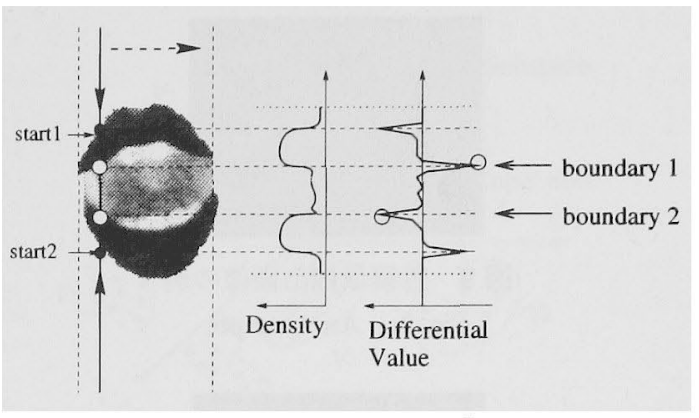

図 6 口内部抽出の手順

Fig. 6. Flow of detection of the inside line of lip

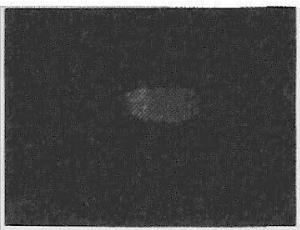

図 7 口内部抽出画像

Fig. 7. An example of detected image of the inside line of lip

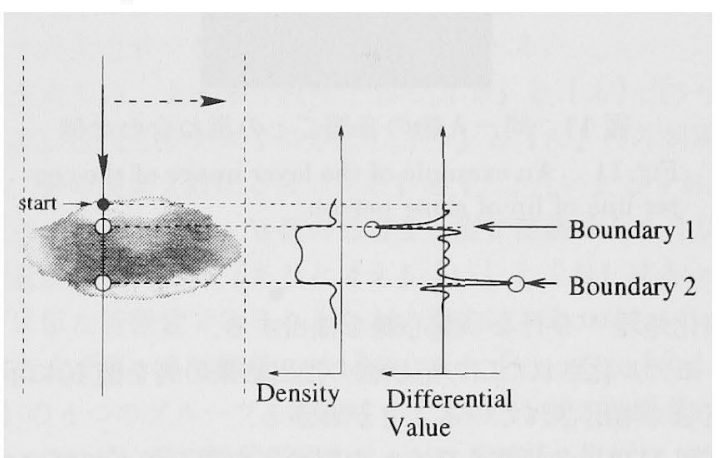

図 8 舌領域の抽出の手順

Fig. 8. Flow of the detection of tangue region

の画像の例を図 7に示す. 正しく口の内側領域が抽出され ていることがわかる.またこの領域の境界が口の内周形状 となる。

$\langle 3 \cdot 3\rangle$ 舌領域の抽出 母音系列の確実な認識を行なう ためには舌情報は重要でる．例えば母音の「あ」と「え」は 外形より舌の使い方に大きな違いが現れる。しかし従来ま でに試みられている方法では，注目されていなかった。

ここでは, 図 $8 に$ 示されるように, 口内側の $\mathrm{Q}$ 成分画像 を微分し，極大值をとる場所が舌領域の境界とする。

舌領域を抽出した例を図 9 に示す. 正しく舌領域が抽出 されているのがわかる.

〈3.4〉モデル化された口の形状モデル化された口の 形状とは，唇の重心線である。唇の外側の形状線や内側の 形状線は，検出誤差やノイズを含むことが多い，そこで唇 の重心線を検出する.

まず口全体の領域画像から口内部領域を除去することで, 唇領域が取り出される。 さらにHilditchの方法を用いて細 


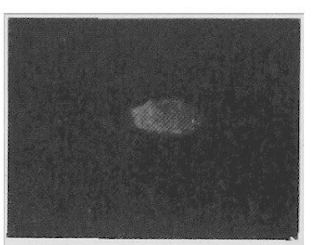

図 9 舌領域抽出画像の例

Fig. 9. An example

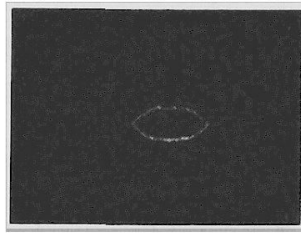

図 10 唇の重心線画像の例

Fig. 10. An example of the center line of lip

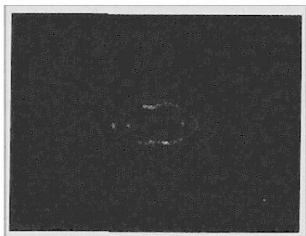

図 11 同一人物の音韻ごとの重ね合わせ例

Fig. 11. An example of the layer image of the center line of lip of same person

\section{線化処理 ${ }^{(8)}$ を行ない重心線を抽出する.}

モデル化された口の形状線の抽出結果の例を図 10 に示す. 正しく抽出されていることがわかる.

図 11は, 各母音を発音した際の唇の重心線を口領域の重 心と画像の中心が重なるように重ね合わせて表示した例で ある. その結果, 外側から「あ」「え」「い」「お」「う」「ん」 の順に示されることになり，6つの母音を発音した際の唇 の重心線は全て異なることが確認される。

また, 5 人の被験者に対し同じ母音ごとに重心線を重ね合 わせた例を図 12 に示す。この図より, 被験者により多少の 口の大きさの違いはあるが, 同じ母音に注目した場合, ほ ほ同心円を描いていることがわかる.

\section{4. 部分空間法による認識}

〈4・1〉特徴量の導出認識を行なう前に, 口領域，口 内部, 舌領域, 唇重心線から, 認識に用いる特徵量の抽出 を行う. 図13に示されるのは，認識に用いることが可能と 思われる特徴量の例である．図 13(a)においては，そのう ちの口全体の面積 ( $S$ ), 口の外形における上側と下側 (真 ん中は口の幅が最も広い部分) の各長さ $(a$ および $b)$ が 示されている. ただし後者の場合, $a$ と $b$ の比が特徴量と なる. (b)においても同様に, 口内部の面積 $\left(S_{\mathrm{in}}\right)$ や口内 部の周囲長 $\left(l_{\text {in }}\right)$, 口の内形における上側と下側の長さ( $a_{\text {in }}$ および $\left.b_{\text {in }}\right)$, 口内部の高さ $\left(H_{\text {in }}\right)$ や幅 $\left(W_{\text {in }}\right)$ など

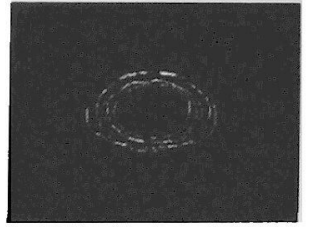

(a)「あ」

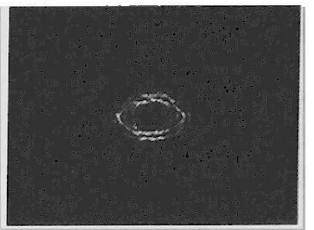

(c)【う」

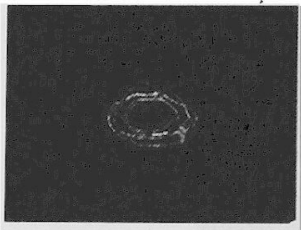

(e)「打】

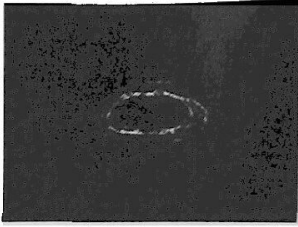

(b) [w]

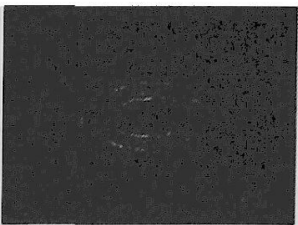

(d)「え】

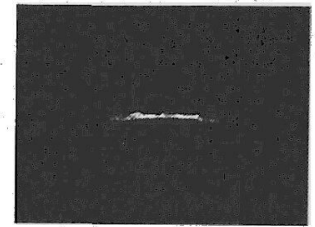

(f) 〔ん】
図 12 同一母音他人物の重ねあわせ

Fig. 12. An example of the layer image of the center lines of lips of some persons

が示されている. (c)においては, 舌領域の面積 $\left(S_{\mathrm{to}}\right)$ が 示されている.さらにこれらの他に, これらの特徴量が複 数個組み合わせられたものや濃淡情報などの全く別なもの が特徴量として抽出する。ただし認識に有効である特徵量 は, 各音韻間で差が大きく, 各個人間で差が小さいものが 望まれる。これらを用いることにより，個性に影響されず に,「あ」,「え」,「い」,「お」,「う」,「ん」の判別が可能に なる。

図 14に算出される特徵量について, 検討した例を示す. 図 14(a) は, 縦軸に口全体の $a b$ 比特徵量を, 横軸に被験者 5 人を並べたものである. 波形に凹凸ができるところから， 個人によってかなり特徵量の值が異なってしまうことがわ かる.すなわちこれは, 各個人の個性に大きく影響されて いるためであり，認識に用いることは好ましくない。

図 14(b) は，同様に口内部の平均濃度值について検討し

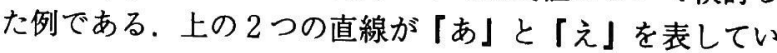
るが，これらはかなり似た值を示してしまっている，しか し他のものは，互いに大きく異なる值をとることがわかる.

図 14(c) に口内部の濃度の標準偏差について検討した例 を示す.これは, 比較的に全ての母音が異なった値をとり， かつそれぞれの母音の直線が平らな形をしていることから， あまり個性に影響されていないことがわかる。このような 検討を繰り返し, 有効と思われる特徴量を用いて, 以下に 示される部分空間を作成する.

〈4·2〉部分空間の作成 音韻の認識には, 図 $15 に$ 示 されるように部分空間法を用いる ${ }^{(9)}$. 部分空間法では対象 


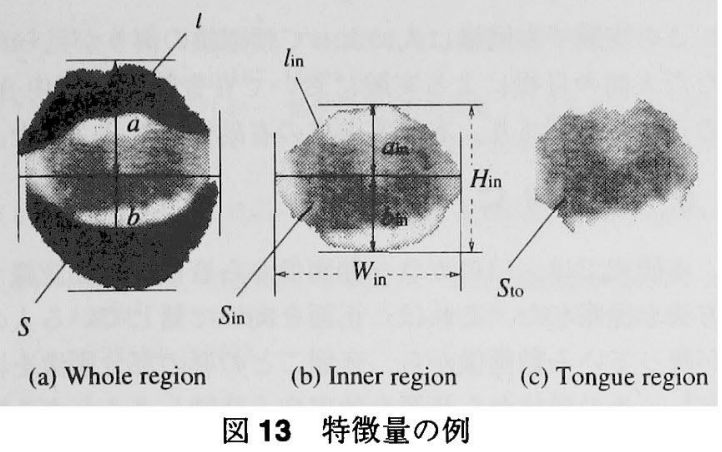

Fig. 13. An example of features

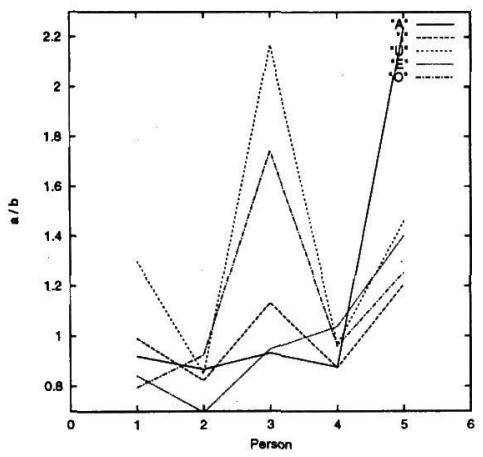

(a)

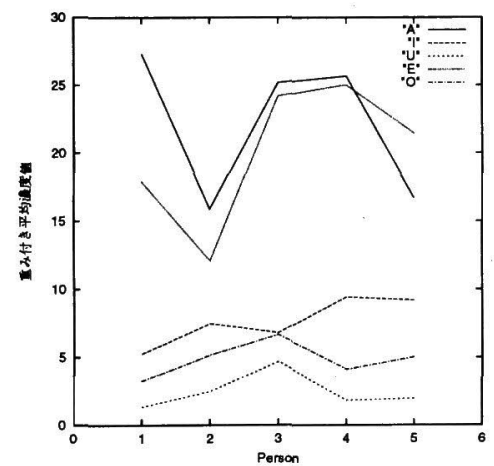

(b)

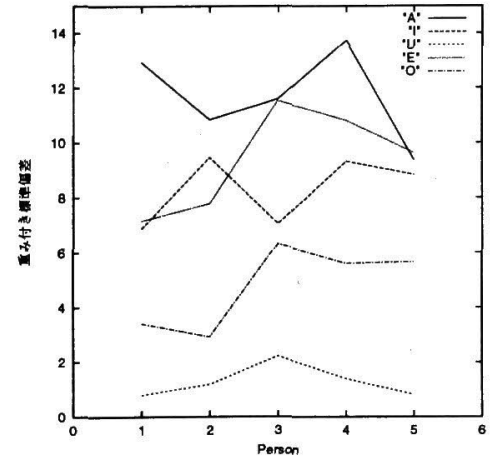

(c)

図 14 特徵量の検討

Fig. 14. Investigation of features

とする $K$ 個のカテゴリを各々 $V_{1}, \cdots, V_{K}$ で表す.まずサ

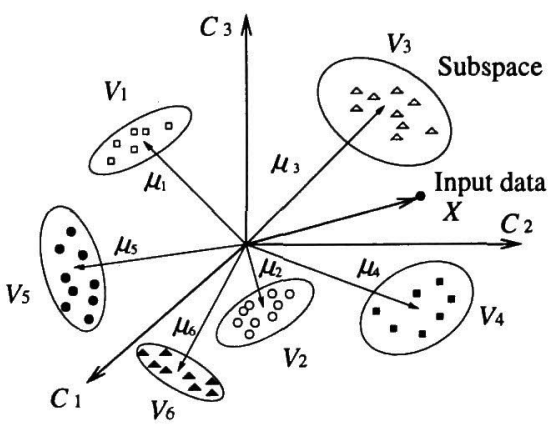

図 15 母音カテゴリーの部分空間

Fig. 15. An example of the subspace

ンプルデータを用いて， $C_{1}, C_{2}, C_{3} \cdots$ で示される特徵空 間内に, $V_{1}, V_{2}, V_{3} \cdots$ の部分空間を生成する.この部分空 間は，その属性ごとのサンプルデータの特徴ベクトル群の 重心ベクトル $u_{1}, u_{2}, u_{3} \cdots$ の周辺に生成される. そして この特徵空間に判別したいデータを入力し，このデータの ベクトル $X$ と各部分空間 $V_{i}$ との距離を求める。このと き, 距離がしきい值以下で，かつ最も距離が短い部分空間 が，その入力データの属性として判別される.

本方式では，まず第 1 段階として，「あ」と「え」,「い」 と「打」は同じカテゴリに分類し「う」と「ん」のみ判別 する。その後第 2 段階として「あ」と「え」、「いと「お」 を判別する。これは， 6 個の母音を一度に認識できそうな 特徴量が少ないこと,「あ」と「え」「い」と「お」は各々, 互いに似た特徴量であることなどの理由による，

本方式で用いる特徵量には,「あ，え」,「い，お」,「う」， 「ん」の 4 つのグループを認識するための 11 個の特徴量が ある.これは, 唇の外周形状のフーリ工記述子, 縦横比, 真 円度, 唇の内周形状の複雑度, 真円度, 口内部の濃度值の平 均值と分散, 舌とその他の比, 口全体の面積と内部の面積 比, 唇の重心線形状の複雑度とフーリエ記述子である。 ま た「あ」と「え」を認識するために $6 つ の$ 特徵量を用いる. これは, 唇の内周形状の真円度, 複雑度, 口内部の濃度值 の平均値と分散, 唇の重心線形状の上側と下側の比 (真ん 中は口の幅が最も広い部分), 接線の平均角度である.「い」 と「お」の認識には 3 つの特徵量を用いる。これは，唇の 内部形状のフーリエ記述子, 口内部の濃度の平均値, 唇の 重心線形状の複雑度である．各特徵空間を形成する特徵量 は，予備実験の結果，決められたものである。

\section{5. 有効性の検証}

〈5・1〉認識実験＼cjkstart認識実験の前にまず特徵空間中に各 音韻の部分空間を作成した. 実験では 5 人 (A さん, $\mathrm{B} さ$ ん, $\mathrm{C}$ さん, $\mathrm{D}$ さん, $\mathrm{E} さ ん)$ の被験者に対して, 3 回ず つ, カラーカメラに向かって,「あ」「い」「う」「え」「お」 「ん」の 6 個の母音を, ゆっくり発音してもらった. そして, 「あ」「い」「う」「え」「お」「ん」の各画像から, 特徴量を 抽出した。これをもとに、「あ，え」と「い，お」と「う」 
表 1 実験結果の一例

Table 1. Examples of measurement results

\begin{tabular}{|c|c|c|c|c|c|c|c|c|c|c|c|c|}
\hline & ta & $\mathbf{n}$ & bo & ta & ni & ya & ma & so & ba & $\mathrm{u}$ & do & n \\
\hline A & 0 & 0 & 0 & 0 & 0 & 0 & 0 & 0 & 0 & 0 & 0 & 0 \\
\hline B & 0 & 0 & & $\mathrm{i}$ & 0 & 0 & 0 & & 0 & 0 & $\mathbf{i}$ & 0 \\
\hline C & $\mathrm{i}$ & 0 & 0 & 0 & 0 & 0 & 0 & 0 & 0 & 0 & 0 & 0 \\
\hline D & 0 & 0 & 0 & 0 & 0 & 0 & 0 & 0 & 0 & 0 & 0 & 0 \\
\hline $\mathbf{E}$ & 0 & 0 & 0 & 0 & 0 & 0 & 0 & 0 & 0 & 0 & 0 & 0 \\
\hline
\end{tabular}

\begin{tabular}{|c|c|c|c|c|c|c|c|c|}
\hline & & & a & ru & & me & & \\
\hline $\mathbf{A}$ & 0 & 0 & & 0 & & & & \\
\hline B & & & & 0 & & & & \\
\hline $\mathrm{C}$ & 0 & & & 0 & & & 0 & \\
\hline $\mathrm{D}$ & $\overline{0}$ & $\overline{0}$ & 0 & 0 & $\overline{0}$ & $c$ & $\sigma$ & \\
\hline & & & $\bar{O}$ & & & $\bar{O}$ & & \\
\hline
\end{tabular}

と「ん」を認識する特徽空間,「あ」と「え」を認識する特 徵空間,「以」と「打」を認識する特徴空間に各々の母音の 部分煠間を作成した。

さらに認識実験として,「たん田」やま」「たに」「うどん」 「そば」「ケーキ」「マルチメディア」の7ワードを，カメラ に向かって，各人のペースで適当に話してもらった，そし て得られたカラー画像データから差分法により処理フレー ムが抽出され，さらに各画像より検出される特徵量が特徴 空間に入力された。この7ワードには，全部で 100 個の音 韻が含まれている。この認識実験の結果を表 1 に示寸。こ れは，正しく認識された場合には○が，正しくされなかっ た場合には，どのような音韻として認識されたかを示して いる。例えば，A さんは「たん甽「たに」、「やま」は正 しく認識されているが，Bさんの場合、「たんほ」の「ぼ が本来ならば「扰になるところが,「い」として認識され ている.

この結果を見ると，音韻 100 個に対して 86 個が正しく 認識されていることがわかる。ただ人によって䛊認識され た母音の種類が偏っている，例えば B さんに注目すると， 全ての母音の誤認識が「いであった。これは，Bされが 大きくロを開けずに音韻を発するために 5 人全員の母音の 部分空間に掠いては，あまり口の開きの少ない母音の「い」 を認識したと考えられる。またほほとんどの誤認識をした 母音は距離では 2 番目の近さであった。人間の読唇能力は, 50７0％と言われる(3)ことから考えると，かなり高い認識 結果が得られている.

〈5-2〉人間の目視による認識寒験本方式を評価する ために，人間の目視による認識を行なった。

まず認識実験に用いた各音韻の処理対象フレーム画像を 紙にプリントアウトした上で，ある人にランダムに見せて いき，母音の判定を行なってもらった。この実験では，被 験者は 10 秒から 15 秒程悩んだ末に認識することが多く見 られた。

ここで用いた単語及び 5 人の被験者の画像は，前述の実 験と同様のもので, 合計 100 シーンあった。その結果, 音 韻 100 個中 85 個の正解率となった。
この実験でも同様に人によって誤認識の偏りが見られた。 ただ人間の目視による実験においても音韻 100 個中 85 個 の正解率に留まり，本提案方式の有効性が確認された。

\section{6. おわりに}

本研究では，ロのカラー動画像から音韻を自動認識する 方法を提案した。これは，正面を向いて話している人の顔 が映っている動画像から，音韻ごとの唇の部分面像を切り 出し，その形状加音韻を効率良く認識しょうとする試み である。ます動画像中の唇の動き情報を用いて，音韻ごと の画像を切り出す．さらにカラー情報をYIQ で表現したと きの Q 成分画像に注目することで唇領域の切り出しを行な う。切り出された唇領域から, さらに濃度変化などを参考 に, 唇の外側输郭線, 内側输郭線, 舌領域, 唇の重心線 抽出する。ささらにそれらより個性に影響されにくい特徽量 を検出して，部分架間法を用いて，音韻を認識する。

本報告ではさらに，実際のシーンに適用した実験結果に ついて示した，その結果，のべ 100 音韻中 86 個について正 しい認識がなされた。これは人間による認識と比べても良 好な結果であり，本方式の有効性が確認された，今後の課 題は，さらに精度の高い認識を行なうことのできるアルコ リズムの構桑である。本論文では母音の認識に関する実験 について述べたが，子音の認識についても検討する必要が ある。例えば読唇術の場合は，単語もしくは構文を認識す る必要があり，本方式で認識された母音のつながりから子 音を類推するアルゴリズムの構築が必要となる。また特定 人物だけ特定の音韻として認識された例があった，ただし 人間の目でも認識が難しいものを，画像処理を用いて認識 させることも非常に難しい，そこでこの対策としては，あ る音韻からある音韻へ移る際の口の動き情報などを付加さ せて認識する，またもし可能ならば「判別不可能」という判 断を出せる機構を加え, もう一度, 話し直させる(画像デー 夕を取り直す)という方法を用いる，などが考えられる。

(平成 10 年 5 月 25 日受付，同 10 年 8 月 19 日再受付)

\section{文献}

（1）松阊清利，古谷忠莪，黑須影二：“画像処理に上る読唇の陚み一母 音口形の識別㧍よびそれに基づく単語認識 一”, 計測自動制御学会論 文集, Vol.22, No.2, pp.67-74, (1986)

（2）田村進一, 暒見直擬, 岡崎耕三, 光本浩士, 河合秀夫, 副井裕: “工亦 ルギー関数とオプティカルフローを用いた口形輪郭の抽出・補完と 追跡”, 電子情報通信学会技術報告, PRU89-20, (1989)

(3) 間製健二, アレックス・アペトランド：“オブティカルフローを用 いた読唇”，電子情垁通信学会論文誌 D-II，Vol.J73-D-II, No.6, pp. $796-803,(1990)$

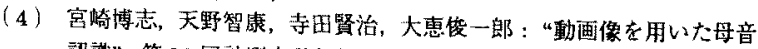
認識”, 第 36 回計測自動制御学会学術罪演会, No.314A-4, pp.903904, (1997)

(5) R.Jain, W.N.Martin and J.K.Aggarwal : "Segmantion through the detection of changes due to motion", CGIP, vol.11, no.1, pp.13-34, (1979) 
（6）高木幹雄, 下田陽久：“YIQ 表色系”, 画像解析ハンドフック, 東京 大学出版会, pp.107, (1991)

（7）道田純治，内村圭一，都甲昌美，相田貞蔵：“言葉の認識にお计る ロ形からのアプローチ”, 電子情報通信学会春季全国大会, pp.150, (1988)

（8）田村秀行：コンビュー夕画像処理入門, 総研出版, pp. 68, pp.85-86, (1985)

（9）伊藤隆太郎, 中澤和夫, 中島真人: “3 次元濐淡顔画像を用いた個 人識別”, 第 3 回画像センシンクシンボジウム講演論文集, No.A-5, pp.29-32, (1997)

寺 田賢 治 (正員) 1990 年 3 月慶應義塾大学理工学部

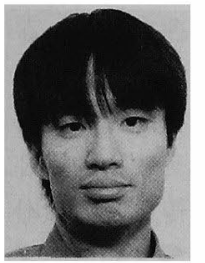
電気工学科卒業. 1995 年 3 月同大学大学 院理工学研究科後期博士課程修了. 同年 4 月徳島大学工学部助手, 同年 11 月同講師. 画像計測, 画像処理に関方る研究に従事. 工学博士. 電子情報通信学会, 電気学会, システム制御情報学会などの会員.
山中 理聖 子 (非会員) 1995 年 3 月徳島大学工学部知能

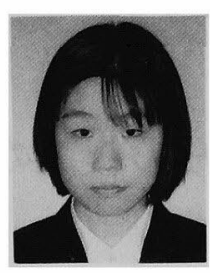
情報工学科卒業. 1998 年 3 月徳島大学大 学院工学研究科前期博士課程修了. 1998 年 4 月労働省入省. 在学中はコンピュータ ビジョンに関する研究に従事.

大 恵 俊 一 郎 (非会員) 1968 年 3 月徳島大学工学部電気

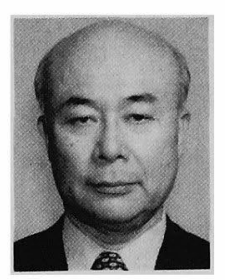
電子工学科卒業. 1970 年 3 月徳島大学大 学院工学研究科修士課程電気工学専攻修 了. 同年 4 月同大学工学部助手. 講師, 助 教授を経て，現在同教授. 1998 年 4 月より 同大棇合情報処理センター長 (併任). 画像 処理, コンピュータビジョン，時系列解析 に関する研究に従事. 工学博士. 電子情報 通信学会, 計測自動制御学会などの会員. 